\title{
LEGAL PROTECTION FOR FOREIGN INVESTMENT IN THE MINERAL AND COAL MINING SECTOR IN IDONESIA
}

\author{
Vania Shafira Yuniar \\ Faculty of Law, Universitas Negeri Semarang \\ vaniashafira2@students.unnes.ac.id
}

Submitted: 2021-04-11 | Reviewed: 2021-04-12 | Accepted: 2021-04-20

\begin{abstract}
How to cite: Vania Shafira Yuniar. "Legal Protection for Foreign Investment in the Mineral and Coal Mining Sector in Indonesia". Dialogia Iuridica: Jurnal Hukum Bisnis dan Investasi, Vol. 12, No. 2, (2021): 102114.
\end{abstract}

\section{DOI:}

https://doi.org/10.28932/di.v12i2.3555

\section{ABSTRACT}

One of the indicators of Indonesia's economic development is investors. Investors are One of the indicators of Indonesia's economic development is investors. Investors are actors who have a role to empower and manage potential resources to serve as the country's economic strength. Mineral and coal mining plays an important role in the national economy and has great potential in the development of the national economy. The purpose of this research is to determine and analyze legal protection for foreign investors in investing in the mineral and coal mining sector in Indonesia. The research method used in this article is normative legal research and through a literature study approach with secondary assessment of legal materials and juridical data analysis. The results of this study indicate that the regulations related to foreign investment in the mining sector are currently using Law Number 25 of 2007 concerning Investment and Law Number 3 of 2020 concerning Amendments to Law Number 4 of 2009 concerning Mineral and Coal Mining. which is considered by the Government as basic regulations that are still in accordance with the 
current conditions of Indonesia, particularly related to legal protection in investment in the mineral and coal mining sector.

Keyword: Coal, Foreign Investment, Minerals, Mining

\section{INTRODUCTION}

The concept of state control over mineral and coal resources in Indonesia is based on the provisions in Article 33 paragraph (3) of the 1945 Constitution, which states, "The land and water and natural resources contained therein are controlled by the state and used to the greatest possible benefit of the people". Article 33 paragraph (3) becomes a doctrine of state control and at the same time serves as a philosophical and juridical basis for the management of natural resources in Indonesia. ${ }^{1}$ The contribution of the mineral and coal mining sector to improving people's welfare in relation to the goal of state control over national natural resources comes from the maxim of the people's welfare. $^{2}$

Indonesia is currently included in the group of developing countries. One of the characteristics of a developing country is development in all fields. In order to increase development in the economic sector, what needs to be considered is investment as capital in carrying out development. Investment is an activity of investing, either directly or indirectly, with the hope that at a later time the owner of the capital will get a number of benefits from the investment. ${ }^{3}$ Investment itself is all forms of investment activities, both by domestic investors and foreign investors. The activity itself uses the funds that come from these investors into economic activities. ${ }^{4}$ Not only the private sector makes an effort to make investment but the government also plays a role. For example, the government has made improvements to infrastructure and added assets. Regional development financing for this infrastructure is usually referred to as capital expenditure. Capital expenditures are expenditures related to investment activities carried out by the government to achieve development targets. ${ }^{5}$

There are many benefits that we can get from the entry of foreign investment into Indonesia. One of them is the entry of new capital to help fund various underfunded

\footnotetext{
${ }^{1}$ Ahmad Redi, Hukum Sumber Daya Alam Dalam Sektor Kehutanan, Jakarta: Sinar Grafika, 2014, p .6

${ }^{2}$ Marthen B. Salinding, "Prinsip Hukum Pertambangan Mineral dan Batubara yang Berpihak kepada Masyarakat Hukum Adat", Jurnal Konstitusi, Volume 16, Nomor 1, Maret 2019

${ }^{3}$ Cana Paranita, Moch. Dzulkirom, AR, Raden Rustam Hidayat, "Analisis Investasi Dalam Reksadana Saham (Equity Funds) Dengan Metode Sharpe dan Treynor". Jurnal Administrasi Bisnis, Volume 27, No. 1,2015, p. 2.

${ }^{4}$ Laurensius Arliman, "Penanaman Modal Asing Di Sumatera Barat Berdasarkan Undang-Undang Nomor 25 Tahun 2007 Tentang Penanaman Modal”, Supremasi Jurnal Hukum, Volume. 1, No. 1, 2018

${ }^{5}$ Reza Lainatul Rizky, "Pengaruh Penanaman Modal Asing, Penanaman Modal Dalam Negeri Dan Belanja Modal Terhadap Pertumbuhan Ekonomi Provinsi Di Indonesia”, JESP: Jurnal Ekonomi dan Studi Pembangunan, Volume. 8, No. 1, Maret 2016
} 
sectors. This foreign investment also opens up many new jobs so that the unemployment rate can be reduced. In addition, the entry of foreign investment is usually accompanied by technology transfer. They bring new technological knowledge to Indonesia which will eventually be developed in Indonesia. It is also possible that foreign investors will cooperate with MSMEs (Micro, Small and Medium Enterprises). The involvement of MSMEs will certainly encourage the economic growth of the community. MSMEs or domestic companies also have the opportunity to market their products to international markets. The most tangible benefit of foreign investment is increasing state income through taxes. In addition, creating a more stable relationship within the economic sphere of the two countries.

One of the natural resources that has the potential to improve people's welfare in Indonesia is mining. ${ }^{6}$ Mineral is a great potential to drive development programs in Indonesia, especially the economic sector. The minerals include gold, silver, copper, oil and natural gas, coal, and others. The minerals are controlled by the state. ${ }^{7}$ The development and utilization of mining materials mentioned above requires a long-term planning and cooperation from competent parties, in this case, foreign investors. Foreign investors have a role not only in increasing the country's economic growth but also in opening up new jobs and transferring technology.

Investment in the mining sector declined in the second quarter of 2019. This is in line with the downward trend in coal prices on the global market. The Investment Coordinating Board (BKPM) noted that investment realization in the second quarter of 2019 based on the smallest sectoral point of view was given by the mining sector, which was in fifth position with a contribution of $7.5 \%$ or as much as Rp 15.1 trillion of the total investment. In fact, mineral and coal mining should be able to make a significant contribution to foreign investment. ${ }^{8}$ In fact, general mining is one of the fields of investment which plays an important role in the continuation of national economic growth in an effort to achieve prosperity and welfare of the people.

Based on the case above, there are several factors that influence the decline in the number of foreign investors in carrying out investment activities in the mining sector in Indonesia. The factors of protection and legal certainty, consistency of legislation, and mining industry policies in Indonesia are among the most highlighted. Many foreign investors consider that investment in Indonesia is difficult to guarantee its security and legal protection due to legal certainty which is considered unstable and consistently protects investors. Even though, in fact, to ensure legal certainty for foreign investors, the government has issued a regulation that can be reference for both parties between the government and foreign investors in the implementation of foreign investment in the mineral and coal mining sector, that is Law Number 3 of 2020 concerning Amendments

\footnotetext{
${ }^{6}$ Victor Imanuel Williamson Nale, "Hak Menguasai Negara Atas Mineral dan Batubara Pasca Berlakunya Undang-Undang Minerba”, Jurnal Konstitusi, Volume 9, No 3, September 2012

${ }^{7}$ Salim HS., Hukum Pertambangan di Indonesia, Revisi III: Raja Grafindo Persada, Jakarta, 2007, p. 1

8 Kontan, 2019, "BKPM Mencatat Investasi Di Sektor Pertambangan Terus Merosot", https://nasional.kontan.co.id/news//kkpm-mencatat-investasi-di-sektor-pertambangan-terusmerosot?page $=1$, accessed on March 30th 2021
} 
to Law Number 4 of 2009 concerning Mineral and Coal Mining. So, based on the background description above, the authors are interested in identifying and analyzing more deeply through normative legal research on legal protection for foreign investors in the mineral and coal mining sector in Indonesia.

The method used in writing this journal is to use normative juridical legal research. Normative legal research or library research is research by examining document studies, namely using a variety of secondary data or data obtained from literature studies such as statute uproaches, court decisions, legal theory, and can be in the form of opinions of scholars with various sources such as books, legal journals, legal dictionaries and the internet related to legal protection against foreign investment in the mineral and coal mining sector in Indonesia.

\section{DISCUSSION}

\section{Regulation of foreign investment in Indonesia}

Foreign investment is a form of transfer of capital, whether real or not, from one country to another or a transfer of capital. The purpose of transferring this capital is used in the country in order to generate profits under the supervision of the owners of capital, both total and partly. ${ }^{9}$ Foreign investment use a flow of capital originating from abroad that come from the private sector through both direct and indirect investment (portfolio). ${ }^{10}$ Foreign Investment is an activity of investing in the territory of the Republic of Indonesia by using foreign capital or by joining forces with domestic investors. ${ }^{11}$ Foreign investment plays an important role in the economic growth of developing countries. It affects the scenarios of employment, production, prices, income, imports, exports, the general welfare of the recipient countries, and the balance of payments and serves as one of the important sources of economic growth. ${ }^{12}$

The background of the issuance of the Investment Law is in accordance with the state's objective is to create a just and prosperous society based on Pancasila and the 1945 Constitution of the Republic of Indonesia, it is necessary to carry out sustainable national economic development based on economic democracy to achieve the goals of a state. Investment in accordance with the mandate stated in the Decree of the People's Consultative Assembly of the Republic of Indonesia Number XVI/MPR/1998 concerning Political Economy in the context of Economic Democracy, investment policies should always underlie a populist economy that involves development for micro, small, medium enterprises and cooperatives.

\footnotetext{
${ }^{9}$ Salim H.S., dan Budi Sutrisno, Hukum Investasi di Indonesia. Jakarta: Grafindo Persada. 2008

10 Indah Ambarsari, "Studi Tentang Penanaman Modal Asing di Indonesia", Jurnal Ekonomi Pembangunan, Volume 6, No. 1, June 2005, p. 26-47

11 Sri Asiyan, "Pengaruh Penanaman Modal Dalam Negeri, Penanaman Modal Asing, Dan Ekspor Terhadap Pertumbuhan Ekonomi Jawa Timur", Jurnal Pendidikan Ekonomi (JUPE), Volume 1 No 3, Agustus 2013

${ }^{12}$ Hussain, M.E.,\& Haque, M. "Foreign Direct Investment, Trade, and Economic Growth : An Empirical Analysis of Bangladesh”, Economies, Volume 4,No. 7, 2016.
} 
The investment law is also expected to accelerate national economic development and realize Indonesia's political and economic sovereignty. It is necessary to increase investment in order to transform economic potential into real economic strength by using capital originating from both within the country and from abroad. In facing changes in the global economy and Indonesia's participation in various international cooperation, it is necessary to create an investment climate that is conducive, promotive, provides legal certainty, justice, and efficiency while still paying attention to the interests of the national economy.

The enactment of the Investment Law is also based on the fact that Law Number 1 of 1967 concerning Foreign Investment as amended by Law Number 11 of 1970 concerning Amendments and Supplement to Law Number 1 of 1967 concerning Foreign Investment and Law -Law Number 6 of 1968 concerning Domestic Investment as amended by Law Number 12 of 1970 concerning Amendments and Supplement to Law Number 6 of 1968 concerning Domestic Investment needs to be replaced because it is no longer in accordance with the needs of accelerating economic development and development of national law, particularly in the field of investment.

With the existence of Investment regulation in Indonesia, the state has opened the door for investors, especially foreign investors to do business in Indonesia, one of which is in the mining sector. ${ }^{13}$ Mining is a business sector that is international in nature, where it will be interconnected with the interests of outsiders who will greatly determine the course of this industry. Foreign investment in Indonesia has been regulated in Law Number 25 of 2007 concerning Investment. According to Article 1 Paragraph 9 Concerning Investment, foreign investment is an activity of investing to carry out business in the territory of the Republic of Indonesia which is carried out by foreign investors, either fully using foreign capital or jointly with domestic investors. Foreign investors are also a way for outside investors to invest by building, buying total or acquiring companies in the territory of the Republic of Indonesia. This foreign capital can drive businesses and at the same time increase the state tax pocket from economic activities carried out by entrepreneurs. In this case what is meant by foreign investors or foreign investors are foreign citizens, foreign legal entities, or foreign governments. Thus, not only foreign legal entities, the colors of foreign countries personally who wish to carry out business activities in Indonesia are also obliged to comply with the provisions in the Foreign Investors Law and its implementation.

The form of the business entity in question is further elaborated in Article 5 stated in paragraph (1) of Law Number 25 of 2007 concerning Investment: Domestic investment can be made in the form of a business entity in the form of a legal entity, not a legal entity or a business. individual, according to statutory provisions. In paragraph (2) Foreign investment must be in the form of a limited liability company based on Indonesian law and domiciled in the territory of the Republic of Indonesia, unless otherwise stipulated by law; Paragraph (3) Domestic and foreign investors making

\footnotetext{
${ }^{13}$ Bobby Keril Mokalu, "Penanaman Modal Asing Di Bidang Pertambangan (Migas) Menurut Hukum Nasional”, Lex Administratum, Volume IV, No. 1, Januari 2016
} 
investment in the form of a limited liability company are carried out by: a. take part of the shares at the time the limited liability company is established; b. buying shares; and c. take other methods in accordance with the provisions of laws and regulations.

With the enactment of Law Number 25 of 2007 indirectly replaces the old law on investment, Law Number 1 of 1967 concerning Foreign Investment and Law Number 6 of 1968 concerning Domestic Investment which has been used. for about forty years. In essence, if we examine it far backward, the ideals of the Indonesian people are the freedom to live independently to build a just and prosperous society on an Indonesian soil which is rich in various natural resources. The ideals of the Indonesian nation are the noble ideals of the nation which were imprinted in the preamble to the 1945 Constitution.

The enactment of Law Number 25 of 2007 concerning Investment, provides the advantage that Indonesia accepts investment activities in the form of foreign and domestic investment. Investment is carried out by forming a business entity in the form of a legal entity, or an individual business, this is in accordance with the provisions of Article 5 paragraph 1 and paragraph 2 of the Law of the Republic of Indonesia Number 25 of 2007 concerning Investment, it states that:

1. Domestic investment can be made in the form of a business entity in the form of a legal entity, not a legal entity or an individual business, in accordance with the provisions of the statutory regulations.

2. Foreign investment must be in the form of a limited liability company based on Indonesian law and domiciled in the territory of the Republic of Indonesia, unless stipulated otherwise by law.

For foreign investors who wish to invest in Indonesia, they must establish a company based on the business fields listed in the KBLI (Indonesian Standard Classification of Business Fields). This foreign company is in the form of a Limited Liability Company (PT) which is owned by at least two shareholders, either individuals or companies. Furthermore, as already mentioned above, investors must pay attention to the guidelines for closed and open business fields with requirements for foreigners listed in Perpres No. 44 of 2016. If the line of business is not listed in the list, it means that foreign share ownership can be up to $100 \%$. The minimum value for foreign investment in Indonesia is IDR 10 billion (excluding land and building prices). The minimum amount of paid-up capital to a bank in Indonesia is IDR 2.5 billion. $^{14}$

\section{Legal protection for foreign investors in the mineral and coal mining sector}

Every investor has the right to security and legal protection. Article 4 of Law of the Republic of Indonesia Number 25 of 2007 concerning Investment states that:

1) The government establishes basic investment policies for:

\footnotetext{
${ }^{14}$ Invest Indonesia, 2019, "Penanaman Modal Asing di Indonesia", https://www.investindonesia.go.id/id/artikel-investasi/detail/penanaman-modal-asing-di-indonesia, accessed on 29 Maret 2021
} 
a. Encourage the creation of a national business climate that is conducive to investment

b. To strengthen the competitiveness of the national economy; and

c. Accelerating the increase in investment.

2) In determining the basic policy as referred to in paragraph (1), the Government:

a) Provide equal treatment for domestic investors and investors foreign capital with due observance of national interests;

b) Guarantee legal certainty, business certainty, and business security for investors since the licensing process until the end investment activities in accordance with the provisions of laws and regulations; and

c) Open opportunities for development and provide protection to micro, small, medium enterprises and cooperatives.

Mineral and coal resources are national assets that must be managed optimally and sustainably for the sake of creating people's welfare. Data from the Ministry of Energy and Mineral Resources, in November 2015 stated that the supply of minerals and coal reached 401,218,566 (tonnes) and supply reserves of 11,494,091 (tonnes). The availability of abundant mineral and coal resources in Indonesia provides an opportunity for the nation to advance the economy through mining efforts. The results of mining management and exploitation can be marketed in both domestic and global markets. ${ }^{15}$

Mining is very important because the returns from its management are quite tantalizing. Unfortunately the management of mining products is not optimal in Indonesia. It is not without reason that this obstacle occurs because funding in this sector requires a very large cost. Coupled with the human resources in Indonesia are not yet capable enough to manage large amounts of mining resources. In the end, to manage mining resources in Indonesia, the government collaborates with the private sector. Many mining companies, including foreigners, are interested in the offer.

Mineral and coal mining business activities have an important role in providing real added value for national economic growth and sustainable regional development, the implementation of which is still constrained by the authority between the Central Government and Regional Governments, licensing, protection of affected communities, mining data and information, supervision, and sanctions, so that the implementation of mineral and coal mining is not effective and has not been able to provide optimal added value.

Regulations regarding mineral and coal mining were previously regulated in Law Number 4 of 2009 concerning Mineral and Coal Mining, but the Law is deemed unable to answer developments, problems and legal needs in the implementation of mineral and coal mining, so changes need to be made so that can be a legal basis that is effective, efficient, and comprehensive in the operation of mineral and coal mining. Therefore, the

\footnotetext{
${ }^{15}$ Kementerian ESDM, "Pasokan Mineral dan Batubara", http://www.bgl.esdm.go.id , accessed on April 4th, 2021
} 
Government together with the DPR-RI have issued Law Number 3 of 2020 concerning Amendments to Law Number 4 of 2009 concerning Mineral and Coal Mining which was promulgated on June 3, 2020.

For better resource management, the government sometimes agrees with foreign parties. Of course the cooperation is carried out in accordance with applicable laws. This is because mining belongs to the government, whose use is intended for the livelihood of many people. In the management of minerals (mining), the government requires very large capital, sophisticated equipment, experts, and there is also a high risk. Indonesia experiences limited funds in exploration and exploitation activities, so it is necessary to have cooperation with foreign investors. ${ }^{16}$ The above should underlie the regulations and policies issued by the government in regulating and managing mineral and coal mines, especially in Indonesia.

Every investor has the right to security and legal protection. Article 4 of Law of the Republic of Indonesia Number 25 of 2007 concerning Investment states that: ${ }^{17}$ The government establishes basic investment policies to encourage the creation of a national business climate that is conducive to investment; to strengthen the competitiveness of the national economy; and accelerating the increase in investment.

In determining the basic policy, the Government already provide equal treatment for domestic investors and investors foreign capital with due observance of national interests; uarantee legal certainty, business certainty, and business security for investors since the licensing process until the end investment activities in accordance with the provisions of laws and regulations; and open opportunities for development and provide protection to micro, small, medium enterprises and cooperatives.

In Indonesia there are several types of mining. Ownership of the mine is $100 \%$ fully owned by the government, private sector, and partly in cooperation with foreign sector ownership. In order to maintain cooperation so that problems do not occur in the future, a mining business permit (IUP) is required by making an agreement called a work contract. In Article 6a of Law Number 3 of 2020 concerning Minerals and Coal, it is stated that the Contract of Work, hereinafter referred to as contract of work, is an agreement between the government and an Indonesian legal entity to carry out Mineral Mining Business activities.

A work contract is a contract that contains an agreement to conduct joint mining businesses between the government of the Republic of Indonesia and the private sector. These private parties can be foreign parties or national private parties. As for mining materials, they are generally grouped into two forms of contract, where the first is specifically for coal exploitation using a contract model known as a Coal Mining Exploitation Work Agreement, while for general mining it is known as a Contract of Work. The form of cooperation is usually a joint funding with the company. The type of business that involves this agreement is in the form of a mining business that involves

\footnotetext{
${ }^{16}$ Aminuddin Ilmar, Hukum Penanaman Modal di Indonesia, Jakarta: Prenada Media, 2006, p. 20

17 Catherine Vania Suardhana, "Perlindungan Hukum Terhadap Penanaman Modal Asing pada Sektor Perkebunan di Indonesia”, Jurnal Hukum Prasada, Vol. 6, No. 1, Maret 2019, pp. 1-14
} 
all sectors apart from oil, gas and natural gas. It can be concluded that a work contract occurs when an agreement is set forth in the form of a written agreement between the Government of Indonesia and a foreign contractor solely and / or is a joint venture between a foreign legal entity and a domestic legal entity to carry out exploration and exploitation activities in the general mining sector for the certain time. ${ }^{18}$

The fundamental difference between a Contract of Work (KK) and a Special Mining Business Permit (IUPK) include agreement status and in the COW, FI and the Indonesian government are 2 contracting parties, their positions are equal. Whereas in an IUPK, the state is the licensor, which is above the company holding the permit. ${ }^{19}$

Meanwhile, Coal Mining Exploitation Work Agreement, hereinafter referred to as PKP2B, is an agreement between the Government of the Republic of Indonesia and an Indonesian legal entity to carry out coal mining business activities. This is as explained in Article 1 point 5.In comparison, the difference between Contract of Work (KK) and Coal Mining Exploitation Work Agreement (PKP2B), as well as mining authority (KP), is in principle based on the legal basis, area size, processing and validation, company activities before the permit is ratified, stages and duration of activities, and fees and taxes collected. ${ }^{20}$

What must be considered in foreign investment in the mining sector is of course whether there are restrictions for foreign investors to carry out business activities in the coal mining sector. This limitation can be checked in Presidential Regulation No. 36 of 2010 concerning List of Business Fields Closed and Business Sectors Opened with Requirements in the Field of Investment. In this DNI Presidential Decree, there are no restrictions for foreign investment in coal mining, therefore it is permissible for foreign investors to have $90 \%$ ownership. What the company has to do is get a permit from Capital Investment Coordinating Board (BKPM). Regarding the licensing procedure from Capital Investment Coordinating Board (BKPM), it has been discussed in this answer.

According to article 5 paragraph (2) of Law no. 25 of 2007 concerning Investment, mandatory foreign investment in the form of a limited liability company. So, later the form of your business and the foreign investor must be in the form of company. Then, it must also be remembered that there are provisions for divestment of foreign investors in the mining sector. Article 112 of Law No. 3/2020 concerning Mineral and Coal Mining (Minerba Law) stipulates that after 5 years of production, business entities holding mining business permits whose shares are owned by foreigners are required to divest $51 \%$ (fifty one percent) of shares. This divestment is carried out at

18 Siti Awaliyah, "Kontrak Karya Dan Perjanjian Karya Pengusahaan Pertambangan Batubara (KK/PKP2B)", Jurnal Pendidikan Pancasila dan Kewarganegaraan, Volume 27, Nomor 2, Agustus 2014

19 Ratnasari Fajariya Abidin, "Harmonisasi Peraturan Penanaman Modal Asing dalam Bidang Pertambangan Mineral Dan Batubara Berdasarkan Prinsip Keadilan (Studi Kontrak Karya antara Pemerintah Republik Indonesia dengan PT. Freeport Indonesia)", Az Zarqa', Volume 9, No. 2, Desember 2017

${ }^{20}$ Ukar W.Soelistijo, "Dinamika Penanaman Modal Asing (PMA) Bidang Pertambangan Umum di Indonesia", MIMBAR, Volume XXVII, No. 1, Juni 2011, p. 79-86 
the Central Government, Regional Government, BUMN, regional owned enterprises, and / or national private enterprises.

Then it is also explained in article 112A that mining bussiness license (IUP) or special mining bussiness license (IUPK) holders, in this case both foreign and domestic investors, are required to provide mineral and coal reserve resilience funds at the Production Operation stage. The mineral and coal reserves resilience fund is used for activities to discover new reserves.

In general, the articles in Law no. 3 of 2020 concerning Mineral and Coal Mining contains 2 types of sanctions, there are administrative sanctions and criminal sanctions given to investors who violate the rules. However, Law Number 4 of 2009 in conjunction with Number 3 of 2020 adopts the ultimum remedium concept. So it is not surprising that the sanctions imposed tend to be in the form of administrative sanctions rather than criminal sanctions. This is as explained in article 151, that the Minister has the right to impose administrative sanctions on holders of mining bussiness license (IUP), special mining bussiness license (IUPK), People's Mining Permit (IPR), Rock Mining Permit (SIPB), or mining bussiness license for Sales for violating the provisions referred to in Article 151 Administrative sanctions as referred to in paragraph (1) are in the form of written warning, fine, temporary suspension of part or all of exploration or production operation activities; and / or revocation of mining bussiness license (IUP), special mining bussiness license (IUPK), People's Mining Permit (IPR), Rock Mining Permit (SIPB), or mining bussiness license for Sales.

Then in article 158 that everyone who carries out mining without a permit as referred to in Article 35 will be sentenced to imprisonment of 5 (five) years and a maximum fine of Rp. 100,000,000,000.00 (one hundred billion rupiah). Criminal regulations are also explained in article 161 that it is also explained that every person who accommodates, utilizes, carries out Processing and / or Purification, Development and / or Utilization, Transportation, Sales of Mineral and / or Coal that does not come from ining bussiness license (IUP), special mining bussiness license (IUPK), People's Mining Permit (IPR), Rock Mining Permit SIPB holders. or permit as referred to in Article 35 paragraph (3) letter c and letter g, Article 104, or Article 105 shall be punished with imprisonment of 5 (five) years and a maximum fine of IDR 100,000,000.00 (one hundred billion rupiah).

Judging from the current facts, after the existence of Law No. 3 of 2020, as quoted from CNN Indonesia page investment in the mining services sector until the third quarter of 2020 reached IDR 70.31 trillion. This number increased quite significantly, namely $25.4 \%$ compared to 2019 which amounted to IDR 56.07 trillion. The mining service industry has also experienced an increase even in the midst of the Covid-19 pandemic this year. This can be seen from the data, the addition of the Mining Service Business Permit (IUJP) to 695 until the third quarter of 2020 from 691 IUJP last year.

The mining service industry has significant impacts due to its multiple effects on the socio-economic life of the communities around the mine and nationally. In addition, the configuration of the mining services sector is not small in state revenue, starting 
from tax revenue which increased to Rp.6.61 trillion in 2019 from Rp.6.52 trillion in 2018. In Law No.3 of 2020 concerning Mineral and Coal Mining, IUJP holders can carry out the mining business sector. The regulation is stated in Article 24 Paragraph 3. In the previous Law, IUJP was only limited to consultation and planning. According to article 124 of Law No.3 of 2020, IUP or IUPK holders are required to use local and / or national mining service companies. Then in the event that there is no Mining Service company,the IUP or IUPK holder can use a Mining Service company that is an Indonesian legal entity for foreign investment. ${ }^{21}$

\section{CONCLUSION}

In the management of mining, especially minerals and coal, the government requires very large capital, sophisticated equipment, experts, and there is also a high risk. Indonesia experiences limited funds in exploration and exploitation activities, so it is necessary to have cooperation with foreign investors. The forms of cooperation carried out in the framework of foreign investment include, among others. Foreign investment in the mineral and coal mining sector which is often carried out in the form of a contract of work as a form of cooperation between foreign investment and national capital occurs when foreign investors form an Indonesian legal entity and this legal entity enters into a cooperation agreement with a legal entity that uses national capital.

Regulations related to foreign investment in the mining sector use Law number 25 of 2007 concerning Investment and Law of the Republic of Indonesia Number 3 of 2020 concerning Amendments to Law Number 4 of 2009 concerning Mineral and Coal Mining which are considered by the Government as a basic rule that is still in accordance with current conditions in Indonesia. In making investments, foreign investors can invest through a Contrct of Work (KK) in accordance to Article 6a of Laws of The Republic Indonesia No. 3 of 2020 About Amendment To Law Number 4 of 2009 About Mineral And Coal Mining. Also, foreign investors can invest through a Coal Mining Exploitation Work Agreement (PKP2B), an agreement between the Government of the Republic of Indonesia and an Indonesian legal entity to carry out coal mining business activities. In addition, the enactment of Law No. 3 of 2020 About Amendment To Law Number 4 of 2009 About Mineral And Coal Mining, indicates an increase in foreign investment in the mineral and coal mining sector in the third quarter of 2020, which previously had a very significant decline in the third quarter of 2019.

\section{REFERENCES \\ Books}

Ahmad Redi, Hukum Sumber Daya Alam Dalam Sektor Kehutanan, Jakarta: Sinar Grafika, 2014.

21 CNN Indonesia, 2020, "Di Tengah Pandemi, Investasi Jasa Tambang Malah Melonjak!", https://www.cnbcindonesia.com/news/20201216184221-4-209615/di-tengah-pandemi-investasi-jasatambang-malah-melonjak, accessed on April 15th, 2021 
Aminuddin Ilmar, Hukum Penanaman Modal di Indonesia, Jakarta: Prenada Media, 2006.

Salim HS., Hukum Pertambangan di Indonesia, Revisi III, Jakarta: PT Raja Grafindo Persada, 2007.

Salim HS., dan Budi Sutrisno, Hukum Investasi di Indonesia. Jakarta: Grafindo Persada. 2008.

\section{Journals}

Bobby Keril Mokalu, "Penanaman Modal Asing Di Bidang Pertambangan (Migas) Menurut Hukum Nasional", Lex Administratum, Volume IV, No. 1, Januari 2016

Cana Paranita, Moch. Dzulkirom, AR, Raden Rustam Hidayat, "Analisis Investasi Dalam Reksadana Saham (Equity Funds) Dengan Metode Sharpe dan Treynor". Jurnal Administrasi Bisnis, Volume 27, No. 1, 2015.

Catherine Vania Suardhana, "Perlindungan Hukum Terhadap Penanaman Modal Asing pada Sektor Perkebunan di Indonesia", Jurnal Hukum Prasada, Vol. 6, No. 1, Maret 2019.

Hussain, M.E.,\& Haque, M. "Foreign Direct Investment, Trade, and Economic Growth : An Empirical Analysis of Bangladesh", Economies, Volume 4, No. 7, 2016, doi : 10. 3390/economies 4020007.

Indah Ambarsari, "Studi Tentang Penanaman Modal Asing di Indonesia", Jurnal Ekonomi Pembangunan, Volume 6, No. 1, June 2005.

Laurensius Arliman, "Penanaman Modal Asing Di Sumatera Barat Berdasarkan Undang-Undang Nomor 25 Tahun 2007 Tentang Penanaman Modal”, Supremasi Jurnal Hukum, Volume. 1, No. 1, 2018.

Marthen B. Salinding, "Prinsip Hukum Pertambangan Mineral dan Batubara yang Berpihak kepada Masyarakat Hukum Adat", Jurnal Konstitusi, Volume 16, Nomor 1, Maret 2019.

Ratnasari Fajariya Abidin, "Harmonisasi Peraturan Penanaman Modal Asing dalam Bidang Pertambangan Mineral Dan Batubara Berdasarkan Prinsip Keadilan (Studi Kontrak Karya antara Pemerintah Republik Indonesia dengan PT. Freeport Indonesia)", Az Zarqa', Volume 9, No. 2, Desember 2017.

Reza Lainatul Rizky, "Pengaruh Penanaman Modal Asing, Penanaman Modal Dalam Negeri Dan Belanja Modal Terhadap Pertumbuhan Ekonomi Provinsi Di Indonesia", JESP: Jurnal Ekonomi dan Studi Pembangunan, Volume. 8, No. 1, Maret 2016, ISSN(P) 2086-1575, E-ISSN 2502-71159.

Siti Awaliyah, "Kontrak Karya Dan Perjanjian Karya Pengusahaan Pertambangan Batubara (KK/PKP2B)", Jurnal Pendidikan Pancasila dan Kewarganegaraan, Volume 27, Nomor 2, Agustus 2014.

Sri Asiyan, "Pengaruh Penanaman Modal Dalam Negeri, Penanaman Modal Asing, Dan Ekspor Terhadap Pertumbuhan Ekonomi Jawa Timur", Jurnal Pendidikan Ekonomi (JUPE), Volume 1 No 3, Agustus 2013. 
Ukar W.Soelistijo, "Dinamika Penanaman Modal Asing (PMA) Bidang Pertambangan Umum di Indonesia", MIMBAR, Volume XXVII, No. 1, Juni 2011.

Victor Imanuel Williamson Nale, "Hak Menguasai Negara Atas Mineral dan Batubara Pasca Berlakunya Undang-Undang Minerba", Jurnal Konstitusi, Volume 9, No 3, September 2012.

\section{Laws and Regulation}

Indonesia Constitution's Law 1945.

Decree of the People's Consultative Assembly of the Republic of Indonesia Number XVI/MPR/1998.

Law Number 3 of 2020 concerning Amendments to Law Number 4 of 2009 concerning Mineral and Coal Mining.

Presidential Regulation No. 36 of 2010 concerning List of Business Fields Closed and Business Sectors Opened with Requirements in the Field of Investment.

Law Number 25 of 2007 concerning Investment.

\section{Other Sources}

CNN Indonesia, 2020, "Di Tengah Pandemi, Investasi Jasa Tambang Malah Melonjak!", https://www.cnbcindonesia.com/news/20201216184221-4-209615/ditengah-pandemi-investasi-jasa-tambang-malah-melonjak, accessed on April 15 th, 2021.

Invest Indonesia, 2019, "Penanaman Modal Asing di Indonesia", https://www.investindonesia.go.id/id/artikel-investasi/detail/penanaman-modalasing-di-indonesia , accessed on March 29th, 2021.

Kementerian ESDM, "Pasokan Mineral dan Batubara", http://www.bgl.esdm.go.id , accessed on April 4th, 2021.

Kontan, 2019, "BKPM Mencatat Investasi Di Sektor Pertambangan Terus Merosot", https://nasional.kontan.co.id/news/bkpm-mencatat-investasi-di-sektorpertambangan-terus-merosot?page =1 , accessed on March 30th, 2021. 